\title{
Prediction of the Potential Daily Output of a Shearer-Loader
}

\author{
Marek Jaszczuk ${ }^{1}$, Arkadiusz Pawlikowski ${ }^{1}$ (D), Wojciech Grzegorzek ${ }^{1}$ and Stanisław Szweda ${ }^{2, *(D)}$ \\ 1 Faculty of Mining, Safety Engineering and Industrial Automation, Silesian University of Technology, \\ Akademicka 2, 44-101 Gliwice, Poland; marek.jaszczuk@polsl.pl (M.J.); \\ arkadiusz.pawlikowski@polsl.pl (A.P.); wojciech.grzegorzek@polsl.pl (W.G.) \\ 2 KOMAG Institute of Mining Technology, Pszczyńska 37, 44-101 Gliwice, Poland \\ * Correspondence: sszweda@komag.eu; Tel.: +48-512-340-029
}

check for updates

Citation: Jaszczuk, M.; Pawlikowski,

A.; Grzegorzek, W.; Szweda, S.

Prediction of the Potential Daily Output of a Shearer-Loader. Energies 2021, 14, 1647. https://doi.org/ $10.3390 /$ en14061647

Academic Editors: Dariusz Prostański and Renato Somma

Received: 15 February 2021

Accepted: 12 March 2021

Published: 16 March 2021

Publisher's Note: MDPI stays neutral with regard to jurisdictional claims in published maps and institutional affiliations.

Copyright: (C) 2021 by the authors. Licensee MDPI, Basel, Switzerland. This article is an open access article distributed under the terms and conditions of the Creative Commons Attribution (CC BY) license (https:/ / creativecommons.org/licenses/by/ $4.0 /)$.

\begin{abstract}
Economic analysis allows for determining the required daily output under certain natural and mining conditions based on the costs of the production process in a particular mine infrastructure. Therefore, there is a need to determine the potential daily output of a longwall using the technical equipment at the disposal of the mine. In the case of mines, when exploiting a few longwalls simultaneously in the conditions of bumping hazards, it is indispensable to ensure safety. Due to a necessity of keeping a safe distance among the longwall fronts, when planning their exploitation, developing a prediction of the longwalls in advance during the planning period is needed. To predict the daily production from a longwall and daily advance of the longwall in the analyzed period, it is necessary to know the current operating time of machines and the capacity of the shearer under given conditions. The current working time of machines results from the available time and the degree of its utilization, which is determined by the sum of unplanned breaks in the production process. The shearer productivity is determined by its haulage speed. Both factors mentioned above are random. Hence, a calculation module has been developed, whose task is to estimate the distribution parameters of these indicators based on empirical data. The algorithm for estimating the parameters of one of the distributions: normal, steady or gamma and its special case of the exponential distribution and Poisson for the obtained input empirical data, constituting a sample from the population, is proposed. The input data are a sequence of numbers obtained from the measurement of the current operating time of machines. These data can be obtained from the longwall shearer memory card, on which its operating parameters are recorded in each longwall. On this basis, it is possible to generate random values of both parameters for individual days of operation. The possibility of determining the haulage speed, based on the longwall shearer's characteristics obtained from the computer simulation of the mining process, is also discussed. The simulation of the mining process is carried out using the GeneSiSv.3.1 software, developed for designing a picks layout on the drum. The characteristics of the shearer production potential also take into account the capacity of loading the cutting drum. It results from the presented characteristics that, when mining coal with a compressive strength of $27 \mathrm{MPa}$, the haulage speed is limited by the loading capacity of the cutting drum and, with greater cuttability, by the power of the electric motor driving the drum. The paper presents algorithms describing the procedure of generating random values necessary for determining the longwall production potential and the daily advance during the assumed period. The subject matter presented in the paper is part of a bigger project which concerns planning of a mine operation and developing a few longwalls in the conditions of bumping hazards.
\end{abstract}

Keywords: shearer capacity; machine operating time; daily output; prediction; economic analysis; safety

\section{Introduction}

In the market economy, a significant problem is determining the minimum daily output which, under certain geological and mining conditions and the specific infrastructure of the mine, justifies running a longwall or starting a new one [1,2]. This minimum volume 
of the daily output of a longwall is a kind of the technical equivalent of the threshold profitability-a tool to determine the amount of profitable production of processing companies [3]. A determination of the daily output from a longwall is a stage of an "elementary decision cycle" [4] in the process of optimizing mining production plans. At present, management processes in the mining industry are supported by dedicated software [5], enabling a visualization of optimized technological schemes in the 3D environment [6]. A versatile use of dedicated information tools, integrated with the monitoring systems, enables a construction of innovative systems for supporting decisions in the scope of conducting production activities in the mining industry [7]. Some examples of applying information tools for an analysis of economic efficiency of production processes from longwalls, exploited with use of a shearer as well as plow technology, are discussed in detail in [8].

An economic efficiency of the coal winning process depends on many factors. For example, in the [9] project, applying a multi-criterial method, the impact of arduous geological and mining conditions on production costs in hard coal mines was analyzed. An occurrence of methane and dust [10] has a significant impact on production rates from a longwall face. Methane and coal dust explosion hazards can be controlled due to an application of spraying installations [11,12]. A technical condition of machines and equipment setting up a technological system [13-15] and an organization of all the operations, starting with equipping a longwall [16] through cutting the solid [17] until a longwall is working and drawing off [18], also have an essential impact on a production efficiency. There is a correlation between daily longwall output, technical and organizational factors and the total cost of coal production covering all the phases of mining, from the cutting of the seam with preparatory activities through the stage of machinery assembly in the longwall, to the phase of liquidation of the selected longwall panel, taking into account the mine infrastructure. The papers $[19,20]$ show that it is possible to determine the daily output in a given longwall panel, which ensures the achievement of profit at the assumed level with the financial expenditures related to the realization of the mining process in the given spatial and technical structure of the mine (Figure 1). The presented example concerns a hard coal mine in Poland, exploiting coking coal deposited in thin seams of thickness below $1.5 \mathrm{~m}$. Due to the exploitational past events and geological dislocations, both the longwall and the panel length are limited, which has an impact on the longwall panel resources. Taking into consideration the coal quality and the demand for coking coal in the metallurgical process, it was indispensable to conduct an economic analysis to enable an efficient production of raw material.

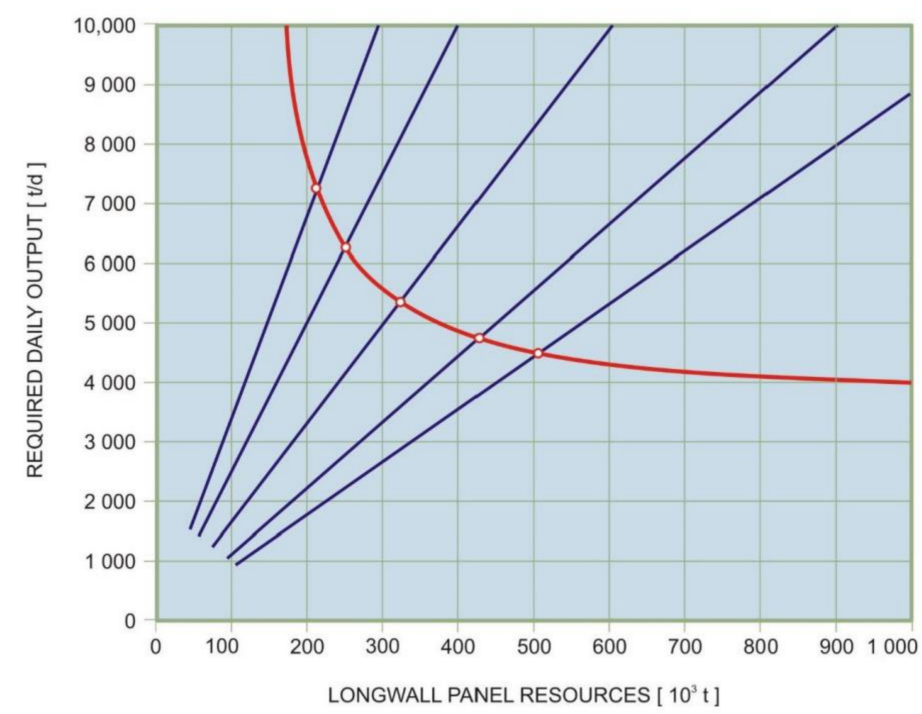

Figure 1. Example of the dependence of required daily output on the resources of a longwall panel [19]. 
In many European hard coal mines (Poland, Russia, Ukraine, The Czech Republic), due to geological conditions and the exploitational past, few longwalls are conducted in panels of limited resources because it is necessary to conduct an economic analysis to ensure an economic efficiency. After having established the required daily production rate, it was necessary to check if it was possible to get it through a determination of a longwall production potential using determined technical equipment. This potential is determined by a shearer-loader capacity in the conditions of a given longwall and the real operational time of machines. In relation to the information given above, a prediction of both mentioned parameters is necessary.

In the case of bumping hazards occurrence, a coordination of developing longwalls in a given panel in terms of safety is indispensable. The principles of developing longwalls explicitly establish a minimal distance which should be maintained among the longwall fronts during the whole period of longwall exploitation. In relation to the situation described above, it is necessary to watch the longwall advances resulting from the obtained output. As both the shearer-loader's productivity in the conditions of a given longwall and the real operational time of machines are parameters of a random character, it is indispensable to conduct a prediction of both parameters for individual days of conducting exploitational processes. It is also necessary to develop an algorithm for a determination of a daily output and advance for a prediction of a development of longwalls during the period of planning the mine operation under analysis.

In relation to the information given above, the objective of the research work is the development of a method for prediction of real operational time of machines and shearer-loader productivity during individual days of exploitational operations and applied procedures, enabling the elaboration of an analytical module for simulation of a production process in a given mine.

\section{Materials and Methods}

To determine the influence of factors determining the production potential of a longwall face, a theoretical model of the production process in a longwall face can be used [14], which allows to determine the daily output of a longwall face, taking into consideration:

- the capacity of the shearer under given operating conditions $Q_{t}$,

- the parameters of the longwall,

- the available operating time of the machines $T$ and the degree of its utilization $\psi_{T}$,

- $\quad$ the mining method ( $\eta_{t}$-shearer efficiency index).

Taking into account the different course of the production process in the longwall resulting from the specificity of the shearer mining method (unidirectional mining, bidirectional mining), the daily output from the longwall can be determined from the relation [14]:

$$
W_{Q}=Q_{t} \cdot T \cdot \psi_{T} \cdot \eta_{t}
$$

The method of mining efficiency index $\eta_{t}$ takes into account the course of the mining process, the current haulage speed of the shearer under given geological and mining conditions and the duration of technological operations at the entry to the longwall.

The theoretical capacity of the shearer under the conditions of a given longwall $Q$ is determined by taking into account the technical parameters of the shearer (nominal web of the cutting drums $z$; maximum shearer haulage speed $v_{\max }$ ) and the parameters related to the natural conditions and the mining system (longwall height $H$; specific density of coal $\gamma$ ) from the following relation [14]:

$$
Q=H \cdot z \cdot v_{\max } \cdot \gamma
$$

Thus, daily output is conditioned by the capacity of the shearer-loader under given geological and mining conditions and the machine operating time. 


\subsection{Prediction of the Current Operating Time of Machines}

To predict the daily output from a longwall in the analyzed period, it is necessary to have two parameters:

- real operating time of machines,

- the haulage speed of the shearer.

The available operating time of machines depends on the adopted system of production organization in the mine (number of shifts, number of production shifts), climatic conditions in the underground of the mine, the distance of the longwall from the shaft and the organization of crew transport to the longwall. It is, therefore, a determined quantity, while the current working time of the machines is random, which results from the occurrence of interruptions in the production process.

Apart from technological interruptions, which are included in the operating time, there are unplanned downtimes, which, due to the cause, can be divided into:

- technical,

- mining,

- organizational.

Technical downtimes result from the unreliability of technical equipment, technical conditions, as well as from operators' mistakes. Due to the serial structure of the technological line for reliability, the number of these breaks, and therefore their total duration, depends on the number of machines carrying out the production process. For example, the failure of the conveyor will not cause downtime if the time of the damage repair is no longer than the time of filling the retention tank, which depends on its capacity and degree of its filling at the moment of damage. Similarly, not every damage to hydraulic roof supports will cause the shearer to stop. The technical equipment stoppage may also be caused by interruptions in electricity and media supply (water, emulsion at the central power supply), which is related to the infrastructure of the mine. The working order of the machines also influences their standstill, which largely depends on the form the organization of the production process. Eliminating or shortening the time of maintenance and repair changes makes it impossible to assess the technical condition, carry out adjustments and replace worn-out elements.

Mining downtimes, apart from those connected with removing the effects of a roof rockslide and pushing out the upper corners of the seam (breaking up large lumps of roof coal, loading them into the conveyors, filling in cavities), also include those caused by an excessive concentration of methane, coal or rock outburst or water outflow. All these interruptions are random, as it is impossible to predict the time and place of occurrence of these phenomena related to the rock mass.

Organizational downtimes may be caused by the lack of auxiliary materials or spare parts. Organizational interruptions may be combined with technical ones, as machine downtime may be prolonged by not emptying the retention tanks or organizing the maintenance services. The above examples show the coincidence of technical, organizational and mining factors.

Therefore, the analytical method cannot be used to predict unforeseen interruptions in the production process due to the number and nature of impact factors.

Introducing the factor of the machine time utilization rate makes it possible to take into account the above-mentioned factors together. This is because each interruption of the technological process results in stopping the shearer-loader.

Since the factor of the machine time utilization rate is random, it has been decided to develop a calculation module whose task is to estimate the parameters of this factor's distribution based on empirical data. Depending on the user's decision, this data may concern individual longwalls, production levels or the whole mine. Since mines have systems for monitoring the operation of machines and each shearer is equipped with a memory card, there is no problem with obtaining the necessary data. 
After the estimation of the distribution parameters of the machine time utilization rate, the module generates random values corresponding to a given distribution for particular days of production. Depending on the user's willingness and invention, it is possible to obtain distributions of the analyzed parameter taking into account, for example, individual days of the week and use them to generate data for simulating the longwall's production potential. The procedure of determining the sequence of parameters of random character is shown in Figure 2.

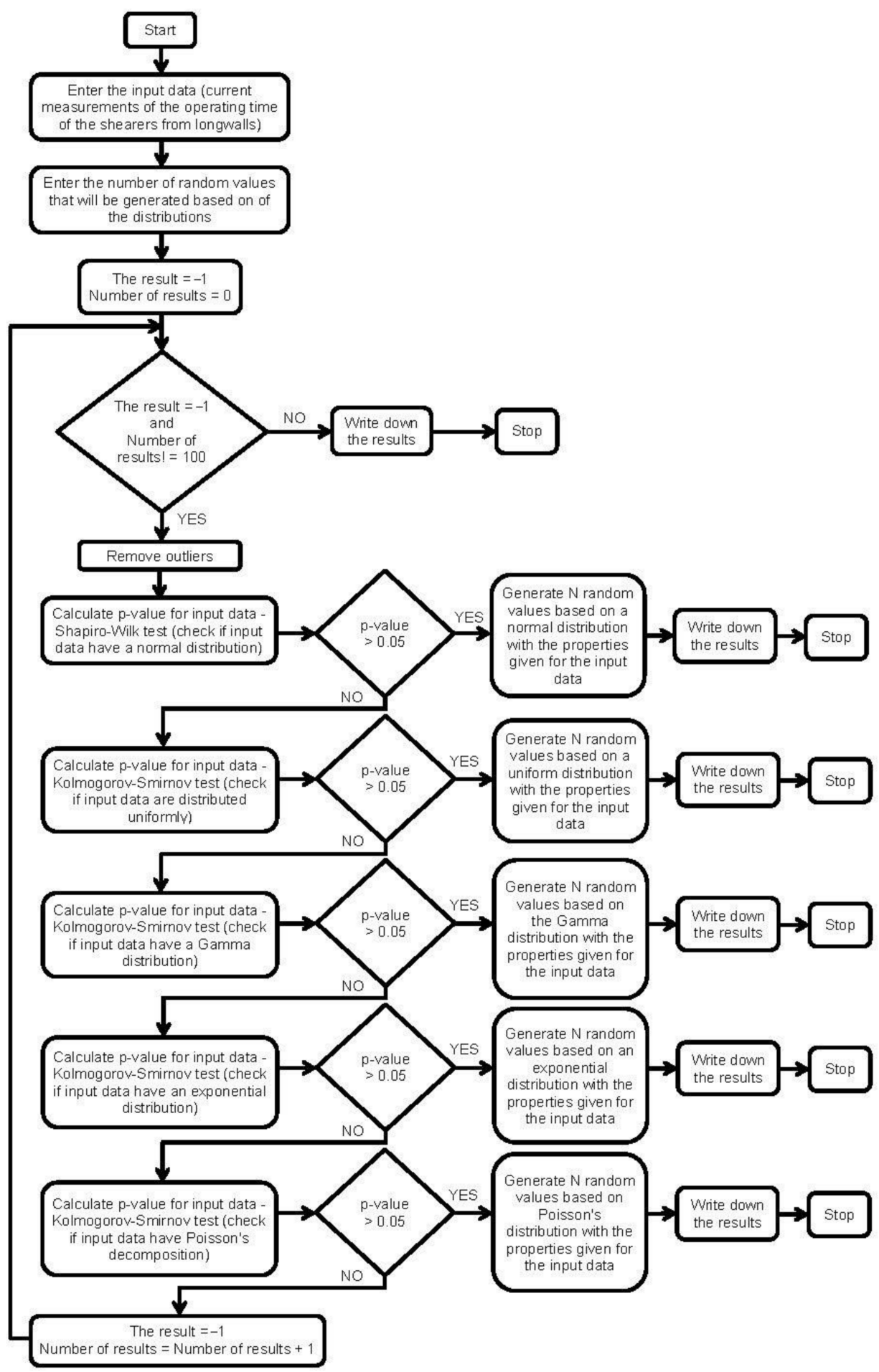

Figure 2. Block diagram of the algorithm for generating random values based on the obtained distribution of the analyzed parameter. 
The algorithm for estimating the parameters of one of the distributions-normal, steady or gamma-and its special case of the exponential distribution and Poisson for the obtained input empirical data, constituting a sample from the population, is proposed. The input data are a sequence of numbers obtained from the measurement of the current operating time of machines. A sequence of number values of the parameter under analysis, which are introduced to the software manually, constitute the input data. Therefore, it does not matter from which record the data are taken and if they are processed preliminarily or if they are in the raw state. The factor of the machine time utilization rate is determined as a quotient of the real operating time of machines and the available time for the analyzed longwall. These data can be obtained from the longwall shearer memory card, on which its operating parameters are recorded in each longwall.

Based on the input data, the output data is obtained in the form of a distribution that describes the input data and its estimated parameters best. On the basis of the obtained distribution, a sequence of random values of the analyzed parameter are generated. The algorithm is written in the $\mathrm{R}$ language. Libraries used for estimating distribution and distribution parameters are: "MASS", "fitdistrplus" and "survival". It is possible to integrate the supplied code with other programming languages such as Python via rpy2.

The estimation of distribution parameters is preceded by the verification of input data by removing outliers. The Grubbs test for the sample size fewer than 30 and the Z-score test for a larger sample were suggested for the removal of outliers. Then it is checked in turn whether the input data have a normal, uniform, Gamma, exponential or Poisson distribution. Data distributions are checked in the given order, and their selection is consistent with the description presented in the block diagram. If one of the successively considered distributions describes the input data well, random values are generated based on this distribution and the other data distributions are not considered.

\subsection{Prediction of the Shearer Efficiency Index}

According to the model presented in the introduction to the prediction of daily longwall mining, it is necessary to determine the shearer efficiency index for the selected mining method. To reach this objective, the following data should be taken into consideration: the longwall length $L$, the length of the shearer-loader $l_{k}$, the rate of participation of technological operations in the mining cycle $p_{z}$ and mining purity index $\eta$. In the case of unidirectional cutting, the haulage speed of the shearer-loader for the mining $v_{u}$ and for the manoeuvring movement $v_{m}$ are different. In the case of bidirectional cutting, both the haulage speed of the shearer-loader and the web width for the upstream mining $v_{z}, z_{z}$ and for the downstream mining $v_{p}, z_{p}$, respectively, can be also different.

This indicator is determined from the following relation [14]: uni-directional mining

$$
k_{o}=\frac{L \cdot \eta}{\left(L-l_{k}\right) \cdot\left(1+\frac{v_{u}}{v_{m}}\right) \cdot\left(1+p_{z}\right)}
$$

bi-directional mining

$$
k_{o}=2 \cdot\left(1+\frac{z_{p} \cdot v_{p}}{z_{z} \cdot v_{z}}\right) \cdot \frac{L \cdot \eta}{\left(L-l_{k}\right) \cdot\left(1+\frac{v_{z}}{v_{p}}\right) \cdot\left(1+\frac{v_{p}}{v_{z}}\right) \cdot\left(1+p_{z}\right)}
$$

It is, therefore, necessary to predict the average value of the shearer haulage speed for both shearer movements (bidirectional mining) or the shearer speed for mining and manoeuvring movements (uni-directional mining).

For this purpose, the module presented earlier can be used to estimate the distribution of the factor of the machine time utilization rate.

By entering the haulage speed values from the memory card of the shearer loader into the module (separately for both phrases), it is possible to obtain the haulage speed distribution of a shearer-loader with the specific power, equipped with cutting drums of 
the given design features under certain geological and mining conditions (coal cuttability, longwall height, a longitudinal and transverse inclination of the longwall). It is necessary to have at disposal the data obtained from previous and other longwalls in a given mine, which should constitute homogeneous groups, taking into account the criteria given above.

By generating average values of the shearer haulage speed on particular days of operation, it is possible to determine the values of the shearer efficiency index. On this basis, taking into account the longwall shearer capacity and the current operating time (also generated at random), it is possible to obtain a prediction of daily output on particular production days during the analyzed period.

The daily advance $p$ of the longwall of the length $L$ and of the height $H$, at the predicted daily output $W_{Q}$, can be determined from the formula:

$$
p=\frac{W_{Q}}{L \cdot H \cdot \gamma}
$$

Through plotting longwall daily advances on individual days of conducting an exploitation of the mining maps, it is possible to check if the correct coordination of developing longwalls in the panel of bump occurrence is kept.

\section{Results}

The order of considering data distributions is based on the most frequently represented distributions for test data. Data distributions that did not occur for test data are added in a random order that does not affect the choice of data distribution because their selection is done by using nested conditional instructions. For the result of the estimation to be reliable, the minimum number of input data for the Shapiro-Wilk test is 3 . For calculation of the remaining distributions, there is no given minimum number of input data as the number 3 is assumed. In Table $1 \mathrm{a}$ test set of input data is presented, and Table 2 shows the results of the module operation based on the entered sample input data.

Table 1. The exemplary set of input data.

\begin{tabular}{cccccc}
\hline \multicolumn{7}{c}{ Value } \\
\hline 11.6 & 2.2 & 3.61 & 6.95 & 7.72 & 4.82 \\
5.7 & 2.39 & 3.7 & 7.27 & 4.16 & 5.52 \\
2.71 & 2.39 & 4.3 & 7.26 & 8.64 & 4.96 \\
2.45 & 2.39 & 3.43 & 6.59 & 10.56 & 5.57 \\
1.94 & 2.39 & 3.32 & 6.05 & 12.24 & 9.27 \\
1.65 & 2.7 & 3.44 & 5.25 & 12.24 & 4.58 \\
1.65 & 3.22 & 3.54 & 5.25 & 6.52 & 5.1 \\
1.74 & 2.8 & 3.89 & 5.65 & 3.69 & 5.6 \\
2.25 & 2.8 & 6.37 & 5.61 & 3.91 & 9.21 \\
2.03 & 3.77 & 4.17 & 6.72 & 6.47 & 6.1 \\
\hline
\end{tabular}

Table 2. The exemplary results of the calculation based on the developed algorithm.

\begin{tabular}{ccc}
\hline No. & Value & Evaluation Results \\
\hline 1 & 4.929339 & \\
2 & 3.264187 & \\
3 & 6.616524 & \\
4 & 3.417058 & $p$-value for Normal distribution: $4.8 \times 10^{-5}$ \\
5 & 7.849846 & $p$-value for Uniform distribution: $1 \times 10^{-5}$ \\
6 & 3.265644 & distribution of the data is Gamma with shape $=1.9324 ;$ rate $=0.3354$ \\
7 & 6.540578 & \\
8 & 2.023909 & \\
9 & 8.874064 & \\
10 & 2.625890 & \\
\hline
\end{tabular}


Based on the $p$-value, normal and uniform distributions were rejected, and the gamma distribution was accepted. For the estimated parameters of this distribution and for a given number of random values their values were generated.

After multiplying the available machine operating time by the index of its utilization, the prediction of the current machine working time on particular days of the period covered by the analysis was obtained.

A prediction of the average haulage speed in given conditions, before obtaining reliable data for estimation of distribution parameters, can be a problem. For this purpose, it is possible to use the characteristics of the technical potential of a shearer, which allows to estimate the haulage speed of a shearer equipped with electric motors of certain power and cutting drums of given constructional features (diameter, web, picks layout), depending on the coal cuttability in the seam. An example of such characteristics concerning the KSW-880EU shearer, equipped with drums of $1800 \mathrm{~mm}$ diameter and $800 \mathrm{~mm}$ web, is shown in Figure 3.

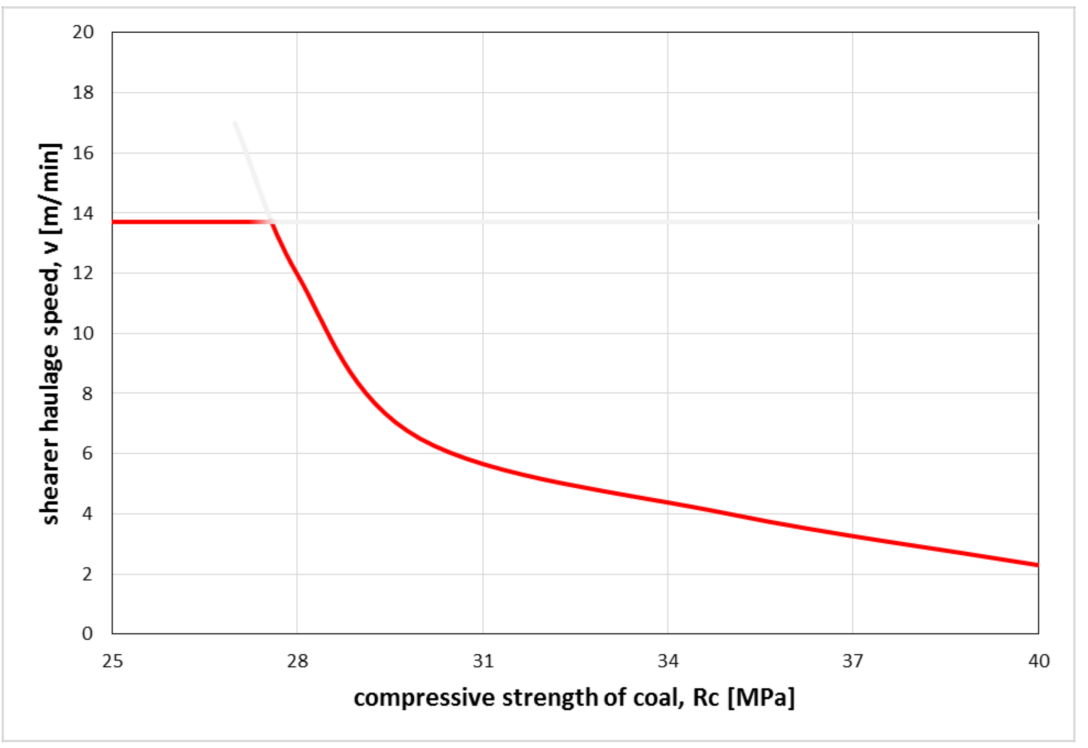

Figure 3. The example of the technical potential of the KSW-880EU shearer loader [21].

These characteristics can be obtained from a simulation of the mining process carried out using the GeneSiSv.3.1 software, developed for designing a picks layout of the drum [22]. In the result of the simulation, the torque course is obtained on the drum shaft for one full rotation (Figure 4) - MoP stands for the cutting drum course and MoT for the loading drum one, respectively.

Since all the currently manufactured shearer loaders are equipped with automatic control of haulage speed, the control map of this system was used to predict the maximum feed rate.

If the overload of the motor driving the cutting drum is $20 \%$ less than the rated load $(\mathrm{Mn} \mathrm{1,X)}$ for a period of $8 \mathrm{~s}$, the haulage speed is automatically reduced. If the overload is more than $20 \%$ and $50 \%$ less than the rated load (Mn 1,Y) and lasts more than $3 \mathrm{~s}$, the haulage speed is also reduced following the haulage speed control algorithm. Since the shearer software averages the instantaneous load with a frequency of $5 \mathrm{~Hz}$, a weighted average was determined for the threshold values and it is possible to determine the maximum feed speed limit under given conditions (Figure 4). 


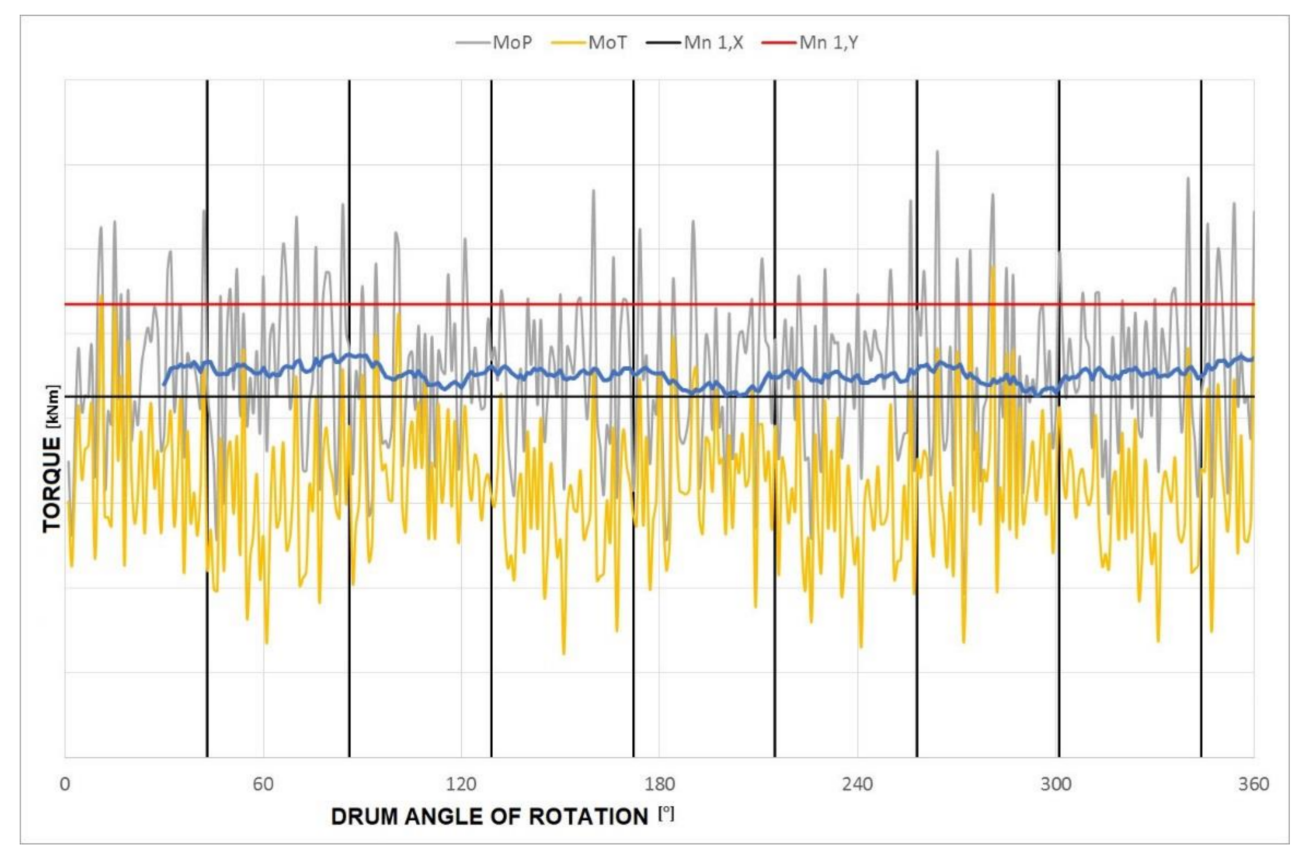

Figure 4. Example of the torque course on the cutting drum shaft as a function of the drum angle of rotation and the average torque, taking into account a multiple of the nominal torque value resulting from the control map.

When determining the load of the motor driving the cutting drum, additional resistances resulting from the loading of the obtained excavated material, according to the relation given in the work [23], are taken into consideration. The torque threshold values of the haulage speed controller were determined taking into account the reducer ratio and the efficiency of the driving system. The characteristics of the shearer production potential also take into account the capacity of loading the cutting drum (Figure 3). It results from the presented characteristics that, when mining coal with a compressive strength of $27 \mathrm{MPa}$, the haulage speed is limited by the loading capacity of the cutting drum and, with greater cuttability, by the power of the electric motor driving the drum.

The analysis of the results of shearer-loaders presented in the paper [23] showed that the distribution of the shearer-loader haulage speed, under the conditions of a given longwall, can be described by means of a normal distribution. The standard deviation of shearer haulage speed in individual longwalls varied between 0.57 and 0.79 . The maximum haulage speed of a shearer can, therefore, be determined from the characteristics of the shearer technical potential, and the average speed can be estimated for the adopted value of standard deviation, assuming the normal distribution.

\section{Discussion}

As a result of the economic efficiency analysis, the mine determines the required daily output from the longwall. It is, therefore, necessary to check whether, under certain geological and mining conditions and using the available technical equipment, this is possible.

The procedure for simulating the longwall potential daily output is shown in Figure 5. 


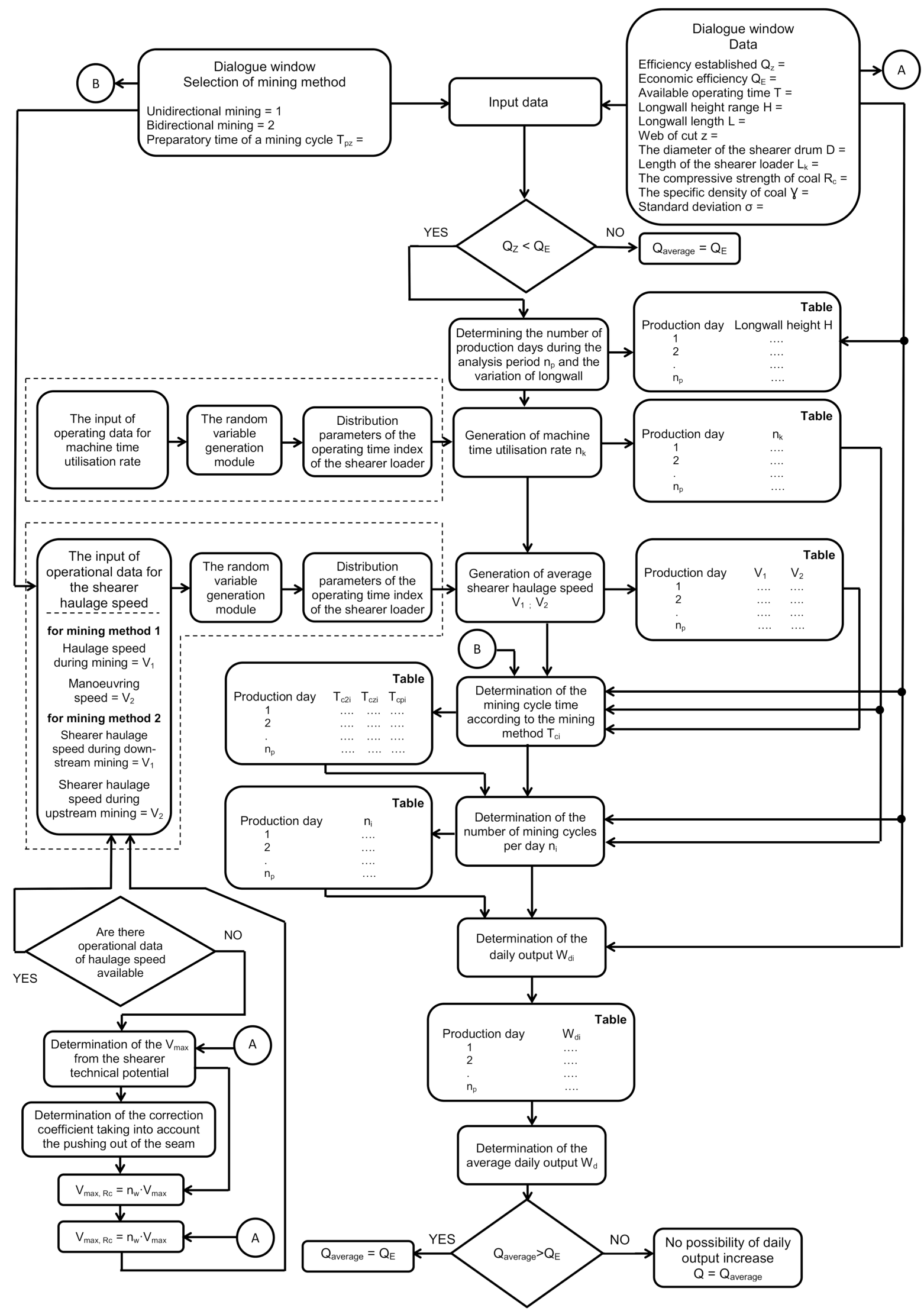

Figure 5. Algorithm showing the procedure for simulating the longwall daily output potential. 
The production potential of a longwall results from the coincidence of the following factors:

- technical,

- organizational,

- impact on the production process of the mining environment.

The parameter necessary to estimate the potential daily output of a longwall is the capacity of the shearer-loader under given mining conditions. It depends on the crosssectional area of the cut layer, haulage speed, method of mining and the time of preparatory operations. In the case of bi-directional mining, the shearer haulage speed can be varied at both turns of the shearer due to the longwall longitudinal inclination or the position of the longwall front in relation to the cleavage. As the daily progress of the longwall changes, the state of tension and deformations in the coal seam changes, which will make the haulage speed random. The current performance of the shearer is also affected by technological breaks and their relation to the time of mining.

The other parameter determining the daily output potential is the real operating time of the machines, resulting from the available operating time and the degree of its utilization. Since the degree of utilization of the available operating time is determined by downtimes resulting from technical, mining and organizational reasons, this factor is random.

According to the procedure presented in the paper, both the above-mentioned parameters of random character are generated on the basis of obtained empirical data, constituting a sample from the population.

A determination of the longwall daily output potential, taking into account random factors including the degree of utilization of available operating time in the longwall and the distribution of the shearer haulage speed, was carried out in accordance with the algorithms presented in the paper. This module was a part of the computer software dedicated to the analysis of the mine production economic efficiency and safety, supporting the process of exploitation planning in the mine developing a few longwalls in bumping conditions.

\section{Conclusions}

1. To ensure economic efficiency in hard coal mines, in which, due to geological conditions and exploitational past events, a few longwalls are developed in the panels of limited resources, it is necessary to establish the required daily output for each of the longwalls.

2. After having established the required output resulting from the economic conditions, a possibility of obtaining it should be checked through a determination of the production potential of the longwall with determined technical equipment. This potential is determined by a shearer-loader's productivity in the conditions of a given longwall and the real operational time of machines. In relation to the information given above, a prediction of both mentioned parameters is necessary.

3. In the case of developing longwalls in the panels where bumping hazards occur, it is indispensable to maintain the minimal distance among the longwall fronts during the whole period of exploitation due to safety reasons. In relation to the facts presented above, the advances of longwalls resulting from the obtained daily output should be watched.

4. A productivity of the shearer-loader in the conditions of a given longwall as well as the real operational time of machines are parameters of a random character. In relation, it is indispensable to predict both parameters for all the longwalls in the panel, taking into consideration individual days of exploitational operations.

5. The GeneSiSv.3.1 software, developed for designing a picks layout on the drum, can be used for a simulation of the mining process. In the result of the simulation, the torque course is obtained on the drum shaft for one full rotation. A simulation is conducted for coal of a set cuttability (compressive and tensile strength) and the accepted solution of the longwall shearer-loader. The following shearer-loader parameters, such as 
power of motors driving the cutting drums, diameter, web depth and a layout of picks on cutting drums, rotational speed of drums and map of automatic control of the haulage speed control system of shearer-loader, are indispensable for this purpose. The conducted simulation enables the prediction of the shearer-loader's haulage speed in the conditions of the given longwall.

6. For the needs of exploitation planning taking into consideration bumping hazards, the methods of predicting real operational time of machines and of longwall shearerloader productivity in the individual days of conducting exploitational operations and the relevant procedures, enabling the development of a computational module for the needs of a simulation of a production process in a given mine, were elaborated.

\begin{abstract}
Author Contributions: Conceptualization, M.J.; methodology, M.J. and A.P.; software, W.G.; validation, S.S.; formal analysis, S.S.; investigation, A.P.; resources, S.S.; data curation, W.G.; writingoriginal draft preparation, M.J.; writing-review and editing, S.S.; visualization, W.G.; supervision, M.J. and S.S.; project administration, M.J. All authors have read and agreed to the published version of the manuscript.

Funding: This article is based on the research results carried out as part of the project entitled "Model and algorithms of multi-criteria economic optimization of mining as a step towards creating the intelligent mine" (UDA-RPSL.01.02.00-24-0700/16-00).
\end{abstract}

Institutional Review Board Statement: Not applicable.

Informed Consent Statement: Not applicable.

Conflicts of Interest: The authors declare no conflict of interest.

\title{
References
}

1. Dvořáček, J. Management of underground mine economy in the period of mining activity damping. In Proceedings of the 9th International Symposium on Mine Planning and Equipment Selection (MPES2000), Athens, Greece, 6-9 November 2000; A.A. Balkema Publishers: Rotterdam, The Netherlands, 2000; pp. 421-436.

2. Markeset, T.; Kumar, U. Application of LCC Techniques in Selection of Mining Equipment and Technology. In Proceedings of the 9th International Symposium on Mine Planning and Equipment Selection (MPES2000), Athens, Greece, 6-9 November 2000; A.A. Balkema Publishers: Rotterdam, The Netherlands, 2000; pp. 635-640.

3. Lisowski, A. The Basis for the Economic Efficiency of Underground Deposit Mining (Podstawy Ekonomicznej Efektywności Podziemnej Eksploatacji Złóż); Central Mining Institute: Katowice, Poland; PWN: Warszawa, Poland, 2001. (In Polish)

4. Lisowski, A. Hard coal mining industry in Poland-A critical assessment of the market transformation and discussion of problems still to be solved 2006-2013. In Górnictwo Wẹgla Kamiennego w Polsce: Krytyczna Ocena Sposobu Przeprowadzenia Rynkowej Transformacji i Dyskusja Problemów Wcią̇̇ Oczekujacych na Rozwiazanie 2006-2013; Central Mining Institute: Katowice, Poland, 2013. (In Polish)

5. Dyczko, A.; Kicki, J.; Myszkowski, M.; Stopa, Z.; Tor, A. New Techniques and Technologies in Thin Coal Seam Exploitation; International Mining Forum, Ed.; CRC Press/Balkema: London, UK, 2013.

6. Kapageridis, I. Input space configuration effects in neural network-based grade estimation. Comput. Geosci. 2005, 31, 704-717. [CrossRef]

7. Wilkinson, W.A. Benefits of building efficient mine planning process. Min. Eng. 2010, 9, 39.

8. Dyczko, A. Methodology of the Run-of-Mine Dilution Impact on the Efficiency of Hard Coal Production Process on the Example of the LW Bogdanka Mine. (Metodyka Oceny Wpływu Zanieczyszczenia Urobku na Efektywność Procesu Produkcji Węgla Kamiennego na Przykładzie LW Bogdanka S.A). Ph.D. Thesis, AGH University of Science and Technology, Kraków, Poland, 2018. (In Polish).

9. Sobczyk, E.J.; Kopacz, M. Assessing Geological and Mining Condition Nuisance and its Impact on the Cost of Exploitation in Hard Coal Mines with the Use of a Multi-Criterion Method. (Uciążliwość warunków geologiczno-górniczych i jej wpływ na koszty eksploatacji w kopalniach węgla kamiennego-Wykorzystanie metody wielokryterialnej-In polish). Arch. Min. Sci. 2018, 3, 665-686.

10. Trenczek, S.; Lutyński, A.; Dylong, A.; Dobrzaniecki, P. Controlling the longwall coal mining process at a variable level of methane hazard. Acta Montan. Slovaca 2020, 2, 159-169.

11. Prostański, D. Development of research work in the air-water spraying area for reduction of methane and coal dust explosion hazard as well as for dust control in the Polish mining industry. In Proceedings of the MEC 2018, Mineral Engineering Conference, Zawiercie, Poland, 26-29 September 2018; pp. 1-13.

12. Prostański, D. Experimental Study of coal dust deposition in mine workings with the use of empirical model. J. Sustain. Min. 2015, 2, 108-114. [CrossRef] 
13. Peng, S.S. Longwall Mining, 2nd ed.; West Virginia University Press: Morgantown, VA, USA, 2006.

14. Jaszczuk, M. Longwall Machinery; Publishing house Śląsk: Katowice, Poland, 2007.

15. Jasiulek, D. Monitoring the operational parameters of powered roof support. J. Mach. Constr. Maint. 2018, 2, 109-115.

16. Prusek, S.; Płonka, M.; Walentek, A. Applying the ground reaction curve concept to the assessment of shield support performance in longwall faces. Arab. J Geosci. 2016, 9, 1-15. [CrossRef]

17. Rajwa, S.; Janoszek, T.; Prusek, S. Influence of canopy ratio of powered roof support on longwall working stability-A case study. Int. J. Min. Sci. Technol. 2019, 29, 591-598. [CrossRef]

18. Mazurek, K.; Szyguła, M.; Turczyński, K. Development of technology for withdrawal of the powered roof support from a row and its relocation from the liquidated longwall system. IOP Conf. Ser. Mater. Sci. Eng. 2019, 679, 012003. [CrossRef]

19. Jaszczuk, M.; Kania, J. Theoretical consideration in establishing the parameters of longwall panel. In Proceedings of the 21st World Mining Congress \& Expo 2008. New Challenges and Visions for Mining, Economics, Management and Design in the Mining Industry, Kraków, Poland, 7-11 September 2008; Publishing house of IGSMiE PAN: Kraków, Poland, 2008 ; pp. 95-106.

20. Jaszczuk, M.; Kania, J. Coal production costs components and coal price as crucial factors in designation of coal output. Arch. Min. Sci. 2008, 53, 183-214.

21. Kozłowski, S. Determination of the Performance Characteristics of the KSW-880EU Shearer Loader on the Basis of Computer Simulation of the Cutting Process (Wyznaczenie charakterystyk eksploatacyjnych kombajnu ścianowego KSW-880EU na podstawie symulacji komputerowej procesu urabiania). Master's Thesis, Faculty of Mining, Safety Engineering and Industrial Automation, Silesian University of Technology, Gliwice, Poland, 2018. (In Polish).

22. Jaszczuk, M.; Cheluszka, P.; Mann, R. Computer Aided Choice of Constructional Features of a Shearer Loader (Komputerowe Wspomaganie Doboru cech Konstrukcyjnych Kombajnu Ścianowego); Publishing House of the Silesian University of Technology: Gliwice, Poland, 2016. (In Polish)

23. Jaszczuk, M. Influence of the Load State of a High-Power Shearer Loader on the Potentiality of Obtaining a High Concentration of Extraction; Publishing House of the Silesian University of Technology: Gliwice, Poland, 1999. 